\title{
Transneuronal Cellular Degeneration in the Somatic Sensory Relay Nuclei in the Cat
}

\author{
I. Dorsal Column Nuclei*
}

By

\author{
John E. Mateer and Hongchien $\mathrm{Ha}^{* *}$ \\ Department of Anatomy, The Milton S. Hershey Medical Center, \\ The Pennsylvania State University, Hershey, Pennsylvania 17033 \\ -Received for Publication, April 10, 1975-
}

\section{Introduction}

The process by which certain neuronal groups within the central nervous system undergo atrophic or frank degenerative changes following interruption of their afferent input has become known as anterograde transneuronal degeneration (Cowan, '70). Relatively undisputed proof of the atrophic process exists in the mammalian visual (Minkowski, '20 ; Cook et al., '51 ; Matthews et al., '60 ; Matthews, '64), auditory (Powell and Erulkar, '62) and olfactory (Powell, '67; Pinching and Powell, 71) systems. A fulminantly degenerative process has been observed in the pontine and inferior olivary nuclei of kittens following rather massive diencephalic and mesencephalic lesions respectively (Torvik, '56b).

Numerous investigators have attempted to demonstrate these same processes in denervated neurons of the spinal cord. Their results, however, are far from conclusive. Dreschfeld $(1879,1880)$ in 1879 described chromatolysis-like transneuronal changes in human spinal cord. According to his literature review similar pathologic changes had been reported as early as 1829 . These early works, however, were postmortem studies of human amputees, had widely. varying degeneration intervals and a highly questionable quality of tissue fixation. Warrington $(1898,1899)$ was one of the first to systematically investigate

* Investigation supported in part by United States Public Health Service Research Grant NB-08168 and General Research Support Grant 5501 RR05680-03. The authors wish to thank Mr. Miles R. Kreider for photography.

** Present address of Dr. John E. Mateer : Department of Medicine, Medical Center Hospital, University of West Virginia, Morgantown, West Virginia 26505. U.S.A. ; Dr. Hongchien Ha: Department of Anatomy, National Yang-Ming Medical College, Taipei, Taiwan, R. O.C. 
transneuronal changes in the spinal cord of animals. Dorsal rhizotomies in the cauda equina of cats and monkeys produced ipsilateral changes in posterolateral cells of the lower thoracic cord. He left the pathologic process to be mild, consisting of Nissl body dissolution and nuclear eccentricity, yet distinct from chromatolysis. Barron ('33) reported chromatolytic changes in cervical and thoracic anterior horn cells of rats following lesions of the corticospinal tract or cervical dorsal rhizotomies. Cook, Walker and Barr ('51), however, using a similar surgical approach in cats, could find no such changes.

The somatic sensory relay nuclei, located in the upper cervical cord and brainstem, have also received much attention in regards to transnouronal changes. Penman and Smith ('50) noted changes of a chromatolytic nature in the medium-sized neurons of the accessory spinal nucleus of the human trigeminal nerve $31 / 2$ months after alcohol injection of the ipsilateral Gasserian ganglion. In addition, small cells in both spinal and main sensory nuclei were observed to be shrunken and dark staining with pyknotic nuclei. Many of these latter cells appeared to be undergoing neuronophagia and cell loss was marked in the main sensory nucleus. Both the chromatolytic and the "pyknotic" cell reactions were attributed to a transneuronal process. Foerster and Gagel ('34) reported chromatolytic changes within the gracilis nucleus of a human following lumbar sacral transsection of the posterior columns. Ferraro and Berrara ('35c), however, could find no such changes in the monkey gracilis, cuneatus or external cuneate nuclei following hemisections at high cervical levels. Recently Loewy ('73) has reinvestigated the effects of dorsal column lesions on cells of the gracilis nucleus in human and monkey material. No changes in microscopic appearance or number of gracilis neurons were noted 22 years after a T-9 cord transsection in a human. While no qualitative changes wcre noted in ceIls of the monkey gracilis 6 months after unilateral mid-thoracic section of the dorsal columns, quantitative analysis revealed a $25 \%$ decrease in mean cell body area and a 20\% decrease in mean nuclear area. In addition $1 \%$ of the gracilis neurons demonstrated increased uptake of reduced silver stains. The controversy regarding the nature of transneuronal changes in the somatic sensory relay nuclei, particularly the dorsal column nuclei (gracilis and cuneatus), is obviously still far from resolved. The present work (Mateer and $\mathrm{Ha},{ }^{2} 72$ ) is an attempt to qualitatively define the nature of transneuronal pathology in the feline dorsal column nuclei (DCN) and to correlate the distribution of this cellular pathology with the well known anatomy and electrophysiology of these first order relays of the dorsal column-medial lomniscal system. 


\section{Materials and Methods}

In the present series of experiments various lesions in both brain and spinal cord were placed in an attcmpt to isolate individual portions of the dorsal column nuclei (DCN) from afferent input. Thirteen adult cats were used; eleven received lesions placed aseptically under pentobarbital anesthesia and two served as normal, unoperated controls. The following types of lesions were made (Table 1):

Table 1

\begin{tabular}{l|c|c|c}
\hline \multicolumn{1}{c|}{ Lesions } & $\begin{array}{c}\text { Degeneration } \\
\text { interval }\end{array}$ & $\begin{array}{c}\text { Number of } \\
\text { animals }\end{array}$ & Staining* \\
\hline $\begin{array}{l}\text { Combined right SM-1 } \\
\text { decortication and left } \\
\text { mid-thoracic dorsal } \\
\text { funiculectomy }\end{array}$ & $\begin{array}{l}60 \text { days } \\
90 \text { days }\end{array}$ & 1 & CV, P A S, P T A H \\
CV, P A S, P T A H, MG P \\
CV, P A S, P T A H, MG P \\
\hline $\begin{array}{l}\text { Bilateral mid-thoracic } \\
\text { dorsal funiculectomies }\end{array}$ & $\begin{array}{l}60 \text { days } \\
90 \text { days }\end{array}$ & 2 & CV, P A S, P T A H, MG P \\
\hline Right SM-1 decortication & 90 days & 2 & CV, P A S, P T A H \\
\hline $\begin{array}{l}\text { Right C5-7, left L6-7, S1 } \\
\text { dorsal rhizotomies }\end{array}$ & 90 days P T A H, MG P \\
\hline Left hemisection at C4-5 & 90 days & 1 & C V \\
\hline Normal controls & & 2 & CV, P A S, P T A H, MG P \\
\hline
\end{tabular}

*Abbreviations : CV-Cresyl Violet, PAS-Periodic Acid Schiff, PTAH-Phosphotungstic Acid-Hematoxylin, MGP-Methyl Green Pyronin.

1. Hemisection of the spinal cord at C4-5. This served to remove most spinal afferents from the ipsilateral gracilis and cuneatus.

2. Bilateral dorsal funiculectomy at mid-thoracic levels. This served to isolate both gracili from their spinal afferents.

3. Unilateral dorsal rhizotomies at C5-7 and contralateral L6-7, S-1 dorsal rhizotomies, on a single animal. The former served to isolate cuneate neurons, the latter gracilis neurons, from only a portion of their spinal afferents in a purely unilateral fashion. This also allowed for effective control tissue in the unaffected member of each paired structure.

4. Unilateral ablation of the sensory-motor (SM-1) cortex. This allowed for the isolation of those neuronal groups within the gracilis and cuneatus which received their afferents from higher centers.

5. A combination of unilateral SM-1 decortication and contralateral mid-thoracic dorsal funiculectomy. This served to isolate the 
gracilis from the majority of its spinal and cortical afferent input.

No postoperative antibiotics were required. All animals made good recoveries.

Animals were sacrificed at 30,60 and 90 postoperative days under pentobarbital anesthesia using a modification of the intracardiac perfusion technique (Matthews et al., '60). One liter of warm $\left(37^{\circ} \mathrm{C}\right)$ physiological saline served as the initial perfusant to insure total blood removal. This was followed by 2 to 3 liters of a warm $\left(37^{\circ} \mathrm{C}\right)$ dilute Karnovsky's solution (Karnovsky, '65 ; Reese and Karnovsky, '67). The entire brain and spinal cord were either removed immediately after perfusion or allowed to remain in situ at $4^{\circ} \mathrm{C}$ overnight prior to removal according to the recommendations of Cammermeyer (Cammermeyer, '62). Tissues were then placed in full strength Karnovsky's fixative (Karnovsky, '65) for 4 hours at room temperature before transfer to a $0.1 \mathrm{M}$ cacodylate buffer and storage at $4^{\circ} \mathrm{C}$.

The segment of spinal cord containing a lesion was embedded in paraffin, sectioned serially at $20 \mu$ and stained with cresyl violet. The lesion was reconstructed using projection drawings made from selected sections within the block, and was represented in a schematic fashion utilizing these drawings (Fig. 1). Cortical lesions were appraised grossly and their extent represented schematically on a standard drawing of the feline telencephalon (Fig. 3). Discontinuity of the sectioned dorsal roots was confirmed grossly using meticulous dissection during removal of the spinal cord.

Sequential blocks of upper cervical cord (C3 to C1) and medulla oblongata (to the medullary pontine junction) were taken from each animal, embedded in celloidin and sectioned serially, in the transverse plane, at $20 \mu$. The majority of sections were stained with cresyl violet. Every tenth or fifteenth section was stained utilizing one of the following: periodic acid Schiff (PAS), methyl green pyronin or phosphotungstic acid-hematoxylin (PTAH) (Lillie, '54; Terner et al., '64).

Projection drawings were made from every tenth or fifteenth section. Each of the serial sections was then examined microscopically for evidence of severely pathological neuronal changes, and these were plotted, according to their location within the DCN, on the appropriate projection drawing for that level. This technique allowed for an approximate estimate of the density and distribution of neuronal pathology within 200 to $300 \mu$ blocks of tissue in a sequential manner. Representative drawings at each often comparable levels in the upper cervical spinal cord and medulla oblongata were then chosen for each animal and composite diagrams were made (Figs. 1, 2, 3). 


\section{Results}

Normal Cytoarchitecture of the DCN. The dorsal column nuclei are composed of the nucleus gracilis and nucleus cuneatus. The former lies medially in the dorsal funiculus and extends from the rostral pole of the second cervical segment to a region slightly rostral to the obex. The latter lies dorsolaterally and extends from the first cervical segment to the caudal limits of the vestibular nuclear complex. In the cat each can be divided into distinct zones based on their appearance in standard Nissl preparations (Taber, '61; Hand, '66; Keller and Hand, '70).

The caudal zone is present only in the gracilis and extends from the caudalmost pole of this nucleus to a point approximately $6 \mathrm{~mm}$ caudal to the obex. Here, large neurons $(20 \times 30 \mu)$ are few in number, occur alone, or in small clusters, and are intermingled with small $(10 \times 10 \mu)$ and medium-sized $(20 \times 20 \mu)$ cells.

A cell nest zone is present in both gracilis and cuneatus. In the former it extends from the rostral border of the caudal zone to a point approximately $2 \mathrm{~mm}$ caudal to the obex. In the latter it extends from the first cervical segment to a point just rostal to the obex. In both nuclei medium-sized $(20 \times 20 \mu)$ cells are arranged in clusters with small $(10 \times 10 \mu)$ neurons located between the clusters or, on occasion, within them. This zone in the cuneatus is further divided into a dorsal portion containing the cell clusters, and a ventral portion where small, and occasional medium-sized cells, are arranged diffusely.

A rostral zone is also present in both nuclei. In the gracilis it extends from the rostral border of the cell nest zone to an ill-defined point 1 to $2 \mathrm{~mm}$ rostral to the obex. In the cuneatus this zone extends from the obex to the caudal limits of the vestibular nuclear complex. In both nuclei small cells are arranged diff usely with occasional mediumsized cells occurring singly or in small clusters.

Neuronal Pathology. Neuronal pathology increased in severity with increasing postoperative survival times. The nature of the individual neuronal pathology, unlike retrograde cellular changes (Liu, '55), was unaffected by the nearness of the lesion to the affected cells. The size of the lesion, and therefore the degree of denervation achieved by it, also correlated very little with the nature of individual cellular changes. The size and level of the lesion, however, did determine the pattern and density of the distribution of transneuronal pathology within the DCN.

Transneuronal pathological changes are described below as they appeared using the cresyl violet method. Description is limited to those changes observed in the gracilis, the cuneatus demonstrating completely analogous changes at equivalent degeneration intervals.

1. 30 day interval

Medium-Sized Neurons: Only mild changes were found. These 
consisted of a relative cytoplasmic hypochromasia when compared to unaffected neurons (Fig. $4 \mathrm{~A}, \mathrm{~B}$ ) in control animals. A mildly disorganized Nissl substance, which tended to accumulate peripherally was noted in these cells (Fig. 4 D). Occasional cells contained large, clear areas of cytoplasm which were devoid of Nissl bodies (Fig. $4 \mathrm{C}$ ). No changes were noted in the nuclei or nucleoli of affected cells.

Small Neurons: These were more widely affected than the medium-sized neurons. Two types of pathological changes were found. Most cells demonstrated mild changes, analogous to those noted in the medium-sized neurons (Fig. $4 \mathrm{D}$ ). Occasional cells demonstratcd a severe pathological change. Their cellular outlines were tortuous and angulated. Their cytoplasm was hyperchromatic and contained few distinct Nissl bodies. Nuclei were shrunken and basophilic.

2. 60 day interval

Medium-Sized Neurons: Two distinct pathological changes were observed. The majority of the altered cells demonstrated an increase in the severity of the mild process noted at 30 days. The degree of disorganization of the Nissl substance was increased: At times these cells presented as extremely hypochromatic "ghosts." Nuclear swelling (Fig. 4G) was also noted in a number of these cells. A minority of the medium-sized neurons demonstrated very severe pathological changes (Fig. $4 \mathrm{E}, \mathrm{F}$ ) consisting of : (a) an angular, tortuous cell shape, (b) loss of all but a small peripheral rim of Nissl substance, giving the cytoplasm a ground glass appearance, (c) cytoplasmic steel-blue orthochromasia to cresyl violet, (d) marked reduction in nuclear size with loss of distinct nuclear-cytoplasmic boundaries, (e) increased nuclear basophilia and (f) an increase in nucleolar size with a decrease in its affinity for cresyl violet.

Small Neurons: As in the 30 day interval, two types of pathological reactions, mild and severe, were noted. At this particular interval, however, the severely affected cells were more numerous.

3. 90 day interval

Medium-Sized Neurons : Uniformly severe pathological reactions were observed in affected cells (Fig. $4 \mathrm{H}, \mathrm{I}$ ). These changes were essentially identical in appearance to those described above at 60 days, except that at the present interval definite atrophy of the involved cells was noted and occasional intracytoplasmic vacuoles were found (Fig. $4 \mathrm{H}$ ).

Small Neurons: These, like their medium-sized counter-parts above, either demonstrated severe pathological reactions or appeared essentially unaltered. Due to the atrophy of the medium- 
sized nourons at this interval, determination of whether a given cell had originally belonged to the small or medium category was difficult.

Histochemical Reactions. Other histological stains were of variable utility in delineating neuronal pathology. All proved to be excellent in the demonstration of severe changes at the 90 and, on occasion, 60 day intervals. None, however, approached the value of cresyl violet when more subtle changes, at earlier degeneration intervals were involved.

Periodic Acid Schiff (PAS): When applied to sections containing severely pathological cells, two patterns were noted: (a) a milder picture where cells demonstrated a marked increase in the accumulation of PAS positive intracytoplasmic granules and (b) a severe picture where a homogeneous PAS positive deposit of a presumed mucoproteinaceous naturc filled the cytoplasm and dendritic processes of the affected cells (Fig. $5 \mathrm{~B}, \mathrm{C}$ ).

Methyl Green Pyronin: This particular technique, in theory (Lillie, '54), is selective for both DNA and RNA, staining the former a greenish-blue and the latter a deep red. Normal neurons appeared much as they did in standard Nissl preparations (Fig. $5 \mathrm{D}$ ). They contained a cytoplasm filled with red Nissl bodies, a clear unstained nucleus and a red nucleolus. Severely pathological neurons (Fig. $5 \mathrm{D}$ ) contained a homogeneous bright red cytoplasm devoid of distinct Nissl bodies. Nuclei of these cells were shrunken, had become varying shades of blue and contained enlarged nucleoli. Occasionally there was evidence of nuclear dissolution, the cytoplasm within these cells contained multiple dark blue granules, in a central to slightly eccentric position, in place of the former nucleus.

Phosphotungstic Acid-Hematoxylin (PTAH): This stain was particularly useful at the 60 and 90 day intervals and allowed for a distinct gradient of pathological changes to be demonstrated in severely affected neurons. Normal neurons appeared as pale yellow discs against a background of dark blue neuropil (Fig. $5 \mathrm{E}, \mathrm{F}$ ). The normal cytoplasm was finely granular and contained many small $(<0.5 \mu)$ blue bodies which represented mitochondria (Lillie, '54). Nissl bodies were not stained. The nucleus was a very pale yellow, slightly eccentric body which contained a bluish-black nucleolus. Moderately severely affected cells demonstrated evidence for a metachromatic shift into the red spectrum (Terner et al., '64). Both cytoplasm and nuclei assumed a dark red color (Fig. 5 F). Nucleoli of these cells were increased in size. More severely affected neurons retained the above red homogeneous cytoplasm, but the nuclei demonstrated 
a complete metachromatic shift into the blue spectrum, were severely shrunken and contained no visible nucleoli. The most severe changes manifested themselves by a total metachromatic shift of both cytoplasm and nuclei into the blue spectrum (Fig. $5 \mathrm{E})$. Dendritic processes of these cells were stained dark blue, were quite prominant and extended for varying distances away from the affected cell body. The cytoplasmic membrane became very angular and occasionally invaginated into intracytoplasmic vacuoles. The latter group of cells was felt to be analogous to the most obviously pathological group visualized in cresyl violet preparations.

Distribution of Transneuronal Pathology in the DCN. The distinctive nature of the individual neuronal pathology noted at the 90 day degeneration interval made the following qualitative analysis of the distribution of these changes within the DCN possible. These observations are presented in relation to the previously described zonal division of the gracilis and cuneatus respectively.

1. Nucleus Gracilis

Effects of Bilateral Mid-Thoracic Dorsal Funiculectomy. Bilateral changes were noted throughout the gracilis. The caudal zone was most affected with severe changes in both small and medium-sized cell populations. The cell nest zone contained occasional severe changes involving medium-sized ncurons. These pathological cells were distributed within cell clusters in a near "ratio" fashion of 1 to 3 cells per cluster, the remaining cluster neurons appearing normal or only mildly pathological. The rostral zone contained a few, randomly distributed, severely affected medium-sized neurons.

Effects of Hemisection at C4-5 Figs. $1 ; 6 A, B, C)$. The lesion, although a complete hemisection, did involve the ventromedial portion of the contralateral dorsal funiculus. Severe changes were widespread throughout the ipsilateral gracilis while only infrequent contralateral changes were noted. The caudal zone was again most widely affected. In addition to extensive, severe pathology in both small and mediumsized cells, there was a strong suggestion of a loss of neurons within this zone. The cell nest zone was less widely affected. In the caudalmost half the cell cluster arrangement had disappeared, leaving only randomly distributed, severely affectcd or normal appearing neurons behind. The rostral half of this zone contained a more nearly normal cytoarchitectural pattern. Severely affected medium-sized cells were distributed within individual cell clusters in the proviously mentioned "ratio" fashion, the remainder of the cluster neurons again appearing normal or only mildly pathological. The rostral zone contained more severely affected medium-sized neurons than had been noted in this zone following mid-thoracic dorsal funiculectomy alone. 


\section{HEMISECTION}

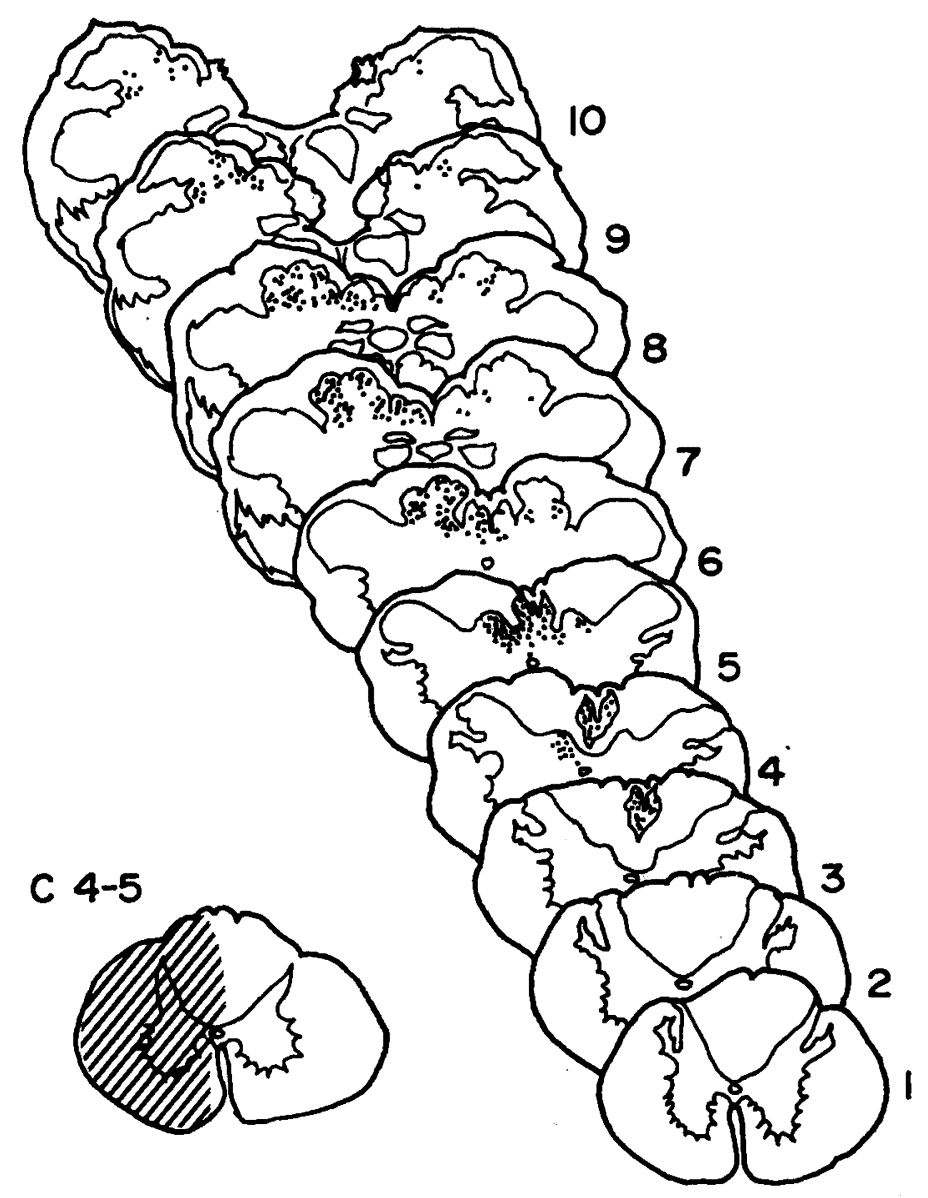

Fig. 1. Schematic representation of the distribution of severe transneuronal pathology within the DCN following left hemisection at C4-5. 90 days interval. Dots represent individual pathological cells but are only placed in a schematic fashion as a means of illustrating relative density of distxibution within representative levels of the DCN. Levels are as follows: (1) Caudal C2. (2) C2. (3) C1-2. (4) C1. (5) rostral C1-medulla oblongata. (6) caudal medulla oblongata. (7)-(10) sections of medulla extending rostrally to a point approximately $2 \mathrm{~mm}$ rostral to the obex. Approximate zonal division of the $\mathrm{DCN}$ is as follows : Gracilis caudal zone (levels 3, 4). Gracilis cell nest zone (levels 5-7). Gracilis rostral zone (levels 8-10). Cuneate cell nest zone (levels 4-8). Cuneate rostral zone (levels 9,10$)$. See text for details.

Effects of L6-7, S1 Dorsal Rhizotomies (Fig. 2). Severe pathology, involving both small and medium-sized neurons, was extensive in the caudal zone of the ipsilateral gracilis. Again there was a suggestion of cellular loss in this zone. Contralateral caudal gracilis neurons 
demonstrated only occasional severe pathological reactions, the remainder appearing normal. The caudal half of the ipsilateral cell nest zone demonstrated mild loss of the cell cluster arrangement. The rostral half of this zone contained the previously described "ratio" of severely pathological medium-sized neurons to normal cells within cell clusters. The rostral zone was devoid of changes. The occasional bilateral changes found in the caudal zone were most likely secondary to inadvertant operative damage to the dorsal funiculi at low lumbar-sacral levels.

DORSAL RHIZOTOMY

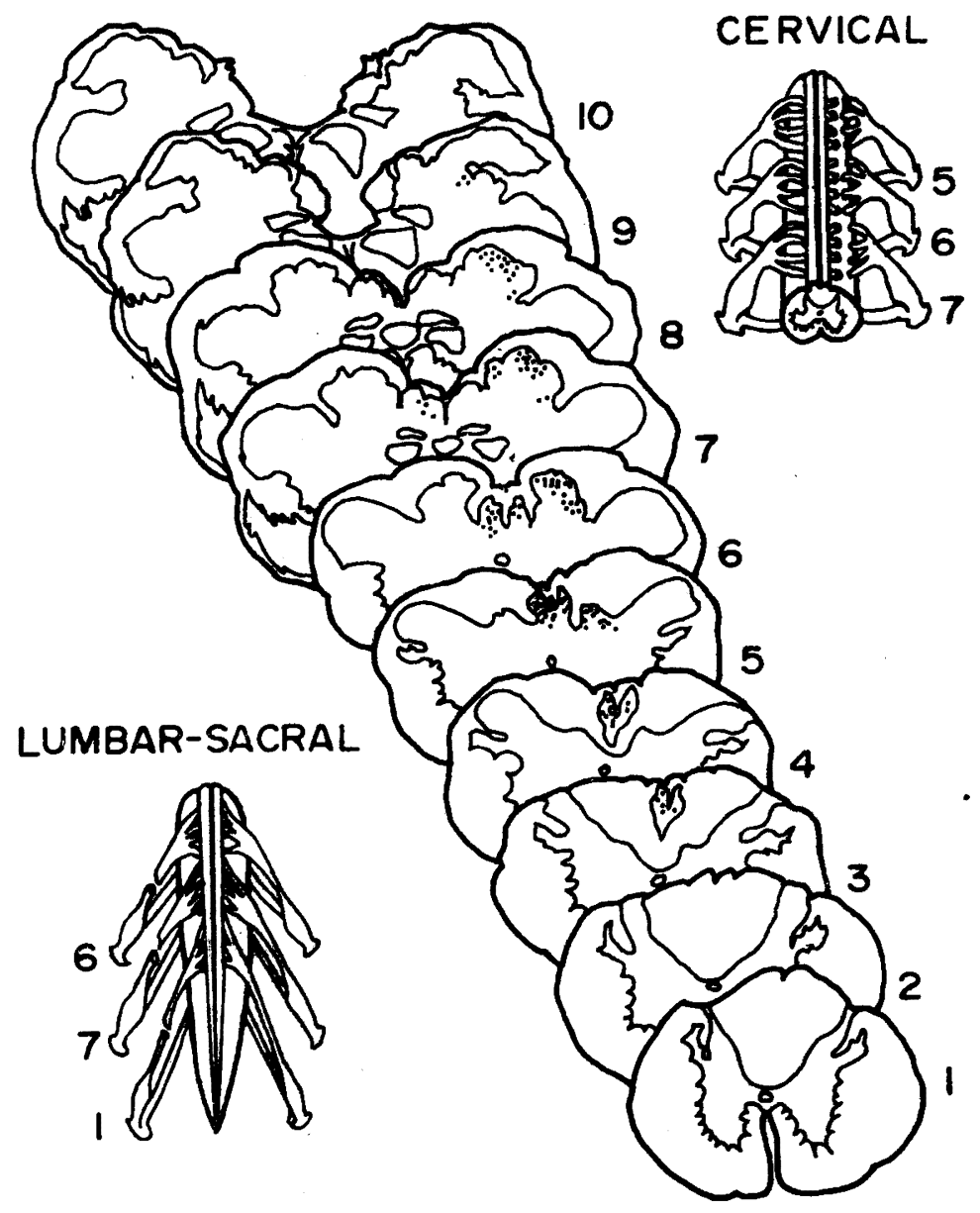

Fig. 2. Schematic representation of the distribution of severe transneuronal pathology within the DCN following right C5-7 dorsal rhizotomies and left L6-7, S1 dorsal rhizotomies. 90 day interval. Levels and zonal division are the same as described in Fig. 1. See text for details. 
Effects of Unilateral SM-1 Decortication (Figs. 3; $7 A, B$ ). Bilateral severe pathological changes, involving both small and medium-sized neurons, were found in the rostral-most portion of the caudal zone. The number of affected cells was slightly greater in the nucleus ipsilateral to the lesion. The cell nest zone contained occasional severely affected small and medium-sized cells located in the ventrolateral portion of the contralateral gracilis. Bilateral changes were again noted in the rostral zone. Just caudal to the obex bilateral groups of severely affected small and medium-sized cells were found in the ventrolateral portions of both gracili. These pathological neuronal groups formed bilateral columns extending in a symmetrical fashion to the rostral borders of these nuclei. The number of pathological cells appeared to be slightly greater in the column contralateral to the lesion.

Effects of Combined Unilateral SM-1 Decortication and Contralateral Mid-Thoracic Dorsal Funiculectomy. The caudal zone contained numerous severely affected small cells and, somewhat less frequent, severely altered medium-sized neurons located ipsilateral to the spinal lesion. The cell nest zone again contained ipsilateral severe medium-sized pathological neurons distributcd within cell clusters in a "ratio" fashion. The distribution of pathology in the rostral zone, however, was different from that noted following purely spinal lesions. Bilaterally symmetrical columns of severely affected cells were located in the ventrolateral portions of both rostral gracili at their junction with the ventromedial portions of the cuneati. These were analogous to the columns noted following unilateral SM-1 decortication alone.

2. Nucleus Cuneatus

Effects of Bilateral Mid-Thoracic Dorsal Funiculectomy. Changes, although bilaterally disttributed, were chiefly unilateral within the cuneatus, occurring ipsilateral to the most severely affected dorsal funiculus. These were limited to an approximate 500 to $800 \mu$ length of the cuneate cell nest zone at the obex level. Medium-sized neurons were severely affected and were randomly distributed throughout this portion of the cell nest zone both dorsally and ventrally. No changes were found in the rostral zone.

Effects of Hemisection at C4-5 Figs. 1; 6 D,E, F, G). The hemisection in this case was complete but extended slightly into the ventromedial portion of the contralateral dorsal funiculus. Severe neuronal pathology was found throughout the entire length of the dorsal portion of the ipsilateral cell nest zone. Only occasional severely affected cells were found in the contralateral nucleus. Pathological medium-sized neurons were distributed throughout cell clusters in a "ratio" fashion similar to that noted in the gracilis cell nest zone (Fig. $6 \mathrm{D}, \mathrm{F}$ ). Dorsolateral and medial cell clusters were most frequently affected. The ventral portion of the cell nest zone contained only occasional severely 
affected medium-sized neurons. The rostral zone likewise contained only occasional severely affected medium-sized cells which were randomly distributed.

Effects of Unilateral Dorsal Rhizotomies at C5-7 (Fig. 2). Severe cellular pathology was again noted throughout the entire length of the ipsilateral dorsal portion of the cell nest zone. No changes were found in the contralateral nucleus. In this case severe pathology was limited to the dorsolateral cell clusters and correlated well with the terminal

\section{SMI CORTICAL ABLATION}

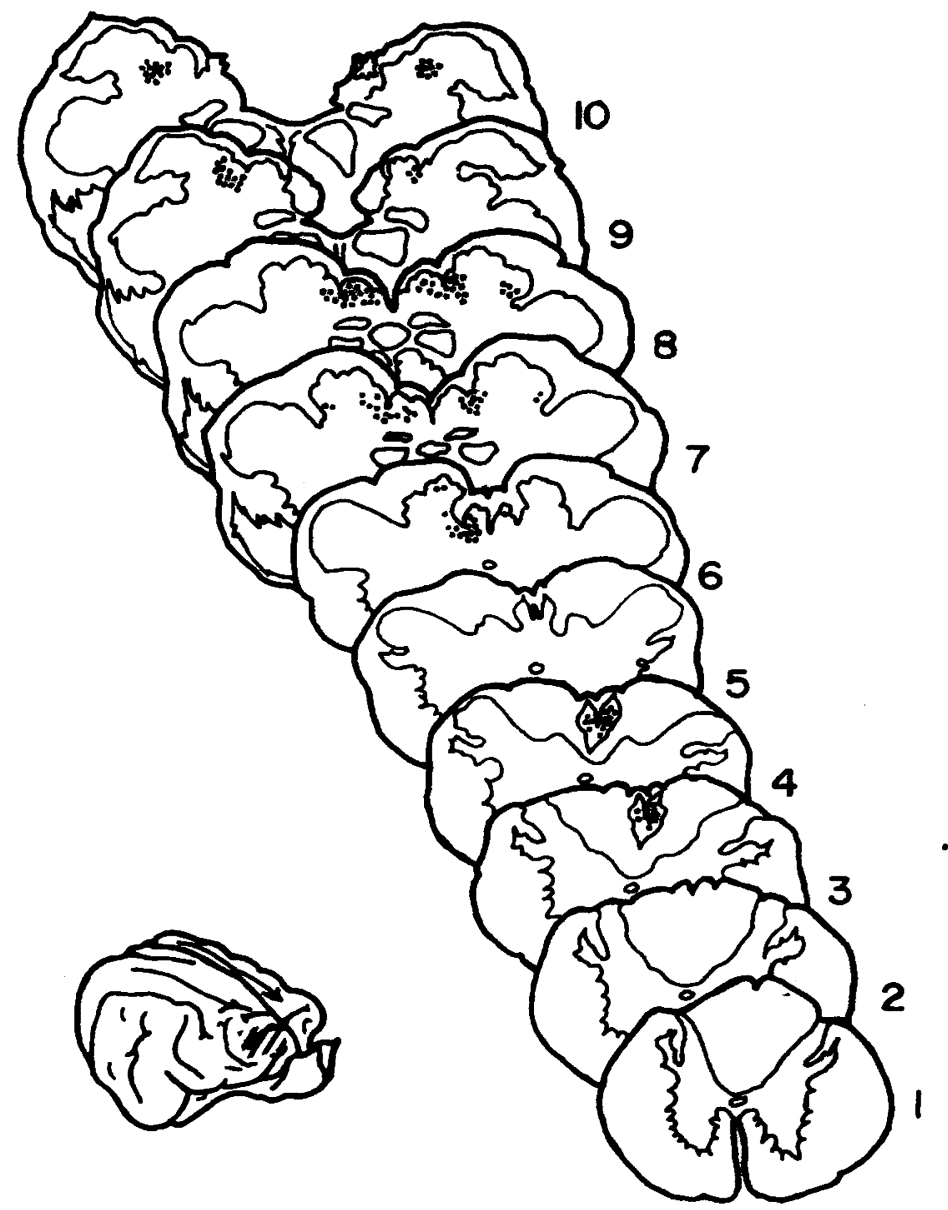

Fig. 3. Schematic representation of the distribution of severe transneuronal changes within the DCN following right-sided SM-1 decortication. 90 day interval. Levels and zonal division are the same as described in Fig. 1. Note the bilateral distribution of changes in the caudal zone of the gracilis (levels $3-4$ ) and the bilaterally symmetrical distribution of pathological cells in the rostral cell nest and rostral zones of both gracilis and cuneatus (levels 7-10). See text for details. 
fields of the roots involved as described by Keller and Hand (70). Again, several medium-sized neurons in each involved cluster demonstrated severe changes, the remaining cells being either normal or only mildly affected. The ventral portion of the cell nest zone contained very few affected cells. The rostral zone was likewise only sparsely involved.

Effects of Unilateral SM-1 Decortication (Figs. $3 ; 7 C, D, E, F$ ). The distribution of neuronal changes following this lesion was described above in relation to the gracilis. Particular reference was made to a bilaterally symmetrical, columnar arrangement of severely affected neurons located in the ventrolateral portions of the rostral gracili. In a strict anatomical sense, the location of the lateral halves of these columns lay within the ventromedial cuneati. Beginning at the obex level, these columns extended rostrally within the cuneati for 2 to $3 \mathrm{~mm}$ through the rostral border of the cell nest zone and into the rostral zone. The number of affected cells was again slightly greater in the column contralateral to the cortical lesion.

Effects of Unilateral SM-1 Decortication and Contralateral MidThoracic Dorsal Funiculectomy. Pathology was distributed in a pattern similar to both that found after mid-thoracic dorsal funiculectomy alone and to that found after unilateral SM-1 decortication alone. In the former case of similarity, severe changes in medium-sized neurons were found within the ipsilateral cell nest zone at the obex level. These cells werc scattered randomly, without any particular relationship to cell clusters, within an approximate $500 \mu$ length of this zone. In the latter case of similarity, a bilaterally symmetrical columnar arrangement of severely affected small and medium-sized cells was found in the ventromedial portions of both cuneati. These columns extended through the rostral cell nest zones and into the rostral zones to a point approximately $2 \mathrm{~mm}$ rostral to the obex. It is interesting that this combined lesion approach did not produce more than merely additive effects on the distribution of transneuronal pathology within this nucleus.

\section{Discussion}

Nature of Transneuronal Pathology. The present work reveals that the coursc and ultimate nature of transneuronal pathology in the DCN is, to a certain extent, distinct from that previously reported in the "classical" lateral geniculate body and auditory relay nuclei (Minkowski, '20 ; Cook et al., '51 ; Matthews et al., '60; Powell and Erulkar, '62 ; Matthews, '64). It is also quite different from that previously reported in spinal cord (Dreschfeld, 1879-1880 ; Warrington, 1898, 1899 ; Barron, '33; Cook et al., '51) and in somatic sensory relays (Foerster 
and Gagel, '34; Ferraro and Barrera, '35c ; Loewy, '73). Based on the appearance of affected cells using cresyl violet preparations alone, we could divide the pathological changes into two distinct but slightly overlapping phases. Mild neuronal pathology was observed in the early phase (30-60 day). This consisted of hypochromatic staining, disorganization of Nissl substance and occasional nuclear swelling. This type of pathology is consistent both in nature and in time course with previous work on the LGB and auditory relays in this same species. Severe cellular pathology was observed in the late phase (60-90 day). These cells had angular, tortuous shapes. Their cytoplasm demonstrated an orthochromatic shift in its staining properties. Their nuclei were shrunken, demonstrated an increased stain affinity and contained enlarged, pale nucleoli. Transneuronal changes of this severity have not been reported in the LGB, even at considerably longer degeneration intervals (Cook et al., '51; Matthews et al., '60; Matthews, '64). A similar pathologic process was noted, however, in the inferior olivary nucleus of kittens (Torvik, '56b), in the small cells of the human trigeminal nuclei (Penman and Smith, '50) and recently, in the rabbit olfactory bulb (Pinching and Powell, '71).

Histochemical techniques were utilized to furthcr define the nature of transneuronal pathology. Methyl green stained the nuclear DNA of severely affected cells, a finding in marked distinction to normal neurons where DNA remains unstained. PTAH revealed an increase in nucleolar size with an associated increase in nuclear basophilia in more mildly affected late phase cells. More severely affected neurons were observed to have extremely basophilic shrunken nuclei. Cytoplasmic alterations, as demonstrated by PTAH, consisted of an increasing content of amino acids (Terner et al., '64) with increasing severity of the pathological process. This accumulation of nonspecific proteinaceous material was most pronounced in the dendritic processes of the affected cells and was noted in the soma only in the extremely pathological members of this group.

A recent electron microscopic study by Pinching and Powell ('71), on transneuronal cellular degeneration in the rabbit olfactory bulb, would seem to reinforce our findings regarding the nature of severe transneuronal pathology. Nuclei of severely affected cells were found to be shrunken and contained densely packed granular material. Nucleoli were enlarged and segregated into granular and fibrillar elements. Cytoplasmic contents were electron dense and contained swollen membrane bound systems. Dendrites were shrunken and contained densely packed neurotubules.

The possible artefactual nature of severe transneuronal pathology, such as that presented above, was discussed by Cammermeyer ('62) in his extensive investigation of the "dark neuron" as it appeared under 
light microscopy. He felt that perfusion, followed by delayed autopsy (which would afford minimal handling of brain tissue in unfixed or early fixed states) was the cure for these neuronal artefacts. Our tissue was perfused with a rapidly penetrating fixative suitable for preparation of tissue for electron microscopy (Karnovsky, '65; Reese and Karnovsky, '67). We could detect no difference in the distribution or nature of the pathologic process between those animals autopsied immediately post perfusion and those in whom autopsy was delayed. No neuronal changes which could not be explained on the basis of the lesions alone were found in any of our material. Assuming that Cammermeyer's criteria were thus adequately met, we must conclude that our described neuronal changes represent true pathology.

Based on the above described features of the pathologic process observed in denervated DCN neurons, perhaps the following model for transneuronal degeneration of this severe nature can be proposed. Denervation (whether acting by removal of unknown trophic factors from, or by constituting an insult to the structural or metabolic integrity of the dendrites or soma) could serve to activate protein synthesis within affected cells. Initial stages of this synthetic process could involve the transcription of previously unexpressed DNA into RNA and the translation of this latter template into protein. This unknown protein may then be transported into the neuronal processes. The most severely affected neurons would then appear to either have poor control of this synthetic pathyway, or a defect in cellular transport mechanisms. The end result is a piling up of the proteinaceous material in the cell body, eventual compression of vital cytoplasmic structures and possible cellular death. It is tempting to further postulate that the unknown protein may represent abnormally polymerized neurofibrils. In this latter sense the pathological process comes to resemble that seen in Alzheimer's pro-senile dementia (Margolis, '59 ; Terry et al., '64).

Further studies are, of course, needed before such a model and analogy can be seriously made. Of particular interest at the light microscope level would be the appearance of affected cells with standard silver techniques or with Congo red staining and subsequent examination under polarized light. Autoradiographic techniques would also be of value in delineating the kinetics of the DNA-RNA interactions within affected cells. Chemical and histochemical studies, similar to those performed on denervated LGB neurons (Kupfer and Downer, '67), are vital to determine the nature of any associated enzymatic changes. Further detailed electron microscopic studies of each stage in the degenerative process are of obvious importance.

Distribution of Severe Transneuronal Pathology within the DCN. A secondary aim of the present study was to determine the utility of transneuronal pathology in defining the cellular sites for afferent 
termination within the DCN. A comparison of our observed distribution of transneuronal pathology within each zone of the DCN, with existing anatomical and electrophysiological data concerning these zones can readily be made.

Existing Nauta studies correlate well with our findings in the caudal zone of the gracilis following spinal deafferentation. Hand ('66) found localized terminal degeneration with some intersegmental overlap within this zone. Electrophysiological evidence indicates that cells of this zone receive monosynpatic, convergent input from dorsal column fibers (McComas, '62). The fact that the density of transneuronal changes in this zone was only slightly less following partial deafferentation (by lumbar-sacral dorsal rhizotomies) than following nearly total deafferentation (by hemisection at C4-5) suggests that total denervation is not a necessary factor for production of transneuronal changes in this zone of the gracilis. If the latter conclusion is valid, then the presence of convergence and intersegmental overlap of afferents from the dorsal columns onto cells of the caudal gracilis is further confirmed.

Nauta studies reveal terminal degeneration in the cell nest zones of both gracilis and cuneatus to be localized with very little intersegmental overlap, within cell clusters (Kuypers and Tuerk, '64; Hand, '66; Keller and Hand, '70). Retrograde changes following destruction of the medial lemniscus affected. most of the cluster cells and spared most of the fusiform, multipolar cells located in the ventral regions of these zones (Kuypers and Tuerk, '64). These studies indicate that cluster cells serve primarily as relay neurons, while the ventrally located cells may serve as interneurons. Electrophysiological studies indicate that cluster neurons have small receptive fields, longer latencies for response to peripheral stimulation than caudal zone cells and transmission that is modulated by afferent inhibition (Gordon and Seed, '61 ; Gordon and Jukes, '62 ; McComas, '62). Andersen et al. ('64c) proposed a model, based on physiologic data, in which ventrally and dorsally located cells serve as the interneuronal mediators for afferent inhibition on cluster relay cells. Transneuronal changes following spinal lesions, while mainly affecting cluster neurons, were limited to only several cells within each cluster. The remainder of the cluster cells appeared normal or were only mildly affected. These findings correlate only partially with the above cited anatomical and physiological data. Parhaps the affected cells are those which maintain the organization of the gracilis caudal zone and receive convergent monosynaptic input from dorsal column fibers. They could then serve as relay cells and/or as interneurons which mediate inhibitory influences to surrounding cluster cells. The fact that the remaining cluster cells are at most only mildly affected may indicate the presence of a delayed secondary transneuronal process. Primary transneuronal degeneration would then affect 
only those cells receiving convergent, monosynaptic dorsal column input. Remaining cluster cells which, in addition to dorsal column input, receive multiple interneuronal influences, may only demonstrate transneuronal changes when the primary transneuronal process becomes sufficiently severe to produce interneuronal alteration. Longer degeneration intervals are obviously needed to investigate this proposal. The fact that the ventral interneurons are largely unaffected by spinal deafferentation simply argues for these cells receiving both spinal and cortical afferents (Gordon and Paine, '60; Gordon and Jukes, '62 ; Andersen et al., '64c ; Kuypers and Tuerk, '64 ; Walberg, '65 ; Walberg, '66a).

Nauta studies regarding spinal afferent termination in the rostral zones of the DCN reveal diffuse, highly overlapping terminal degeneration, reflecting poor somatotopic localization in these regions (Hand, '66; Keller and Hand, '70). Rostral zone cells were only mildly affected by retrograde changes following interruption of the medial lemniscus (Kuypers and Tuerk, '64), a finding in favor of the presence of interneuronal pools within these zones. Many cells of these zones were observed to be fusiform, multipolar interneuronal "types" which received corticospinal afferent termination (Kuypers and Tuerk, '64). Electrophysiological studies revealed cells of these zones to have large receptive fields, high thresholds and very long latencies of response to peripheral stimulation and poor frequency following (Gordon and Seed, '61; McComas, '62). These characteristics were completely opposite to those of caudal zone cells, where monosynaptic relations betwecn dorsal column fibers and gracilis neurons exist, and argues further for the presence of complex interneuronal relationships within the rostral zones. The above studies indicate that our demonstration of only scattered transneuronal pathology within these zones following spinal lesions is completely consistent with a primary transneuronal process affecting only those cells receiving monosynaptic input from dorsal column fibers alone.

Many anatomical (Chambers and Liu, '57 ; Kuypers and Tuerk, '64 ; Walberg, '65 ; Kusama et al., '66 ; Walberg, '66a) and electrophysiological (Levitt et al., '60 ; Towe and Jabbur, '61 ; Chambers et al., 63 ; Gordon and Jukes, '64b; Gordon and Miller, '66) studies have been conducted on the cortical projections to the DCN of the cat. Terminal degeneration following unilateral frontal decortication in the cat was preferentially distributed to those regions of the DCN containing fusiform, multipolar cells, and was sparse in regions containing cluster cells (Kuypers and Tuerk, '64). The former regions were demonstrated to be the ventral portions of the caudal and cell nest zones and the majority of the rostral zones of the DCN (Kuypers and Tuerk' '64). Electrophysiological models based on the feline cuneatus proposed the 
presence of cortically activated pre and postsynaptic inhibitory interneurons which medulate transmission through the cluster relay cells (Andersen et al., '64c). These interneurons were found to be located in regions of the cuneatus containing the fusiform, multipolar cells. An ultrastructural basis, in the form of axo-axonic synapses, for the postulated presynaptic inhibition was found in the ventral portions of the feline cuneatus (Walberg, '65 and '66a).

A bilateral, circumscribed group of caudal gracilis neurons was involved by transneuronal changes following unilateral cortical (SM-1) lesions. These cells were also affected by spinal lesions alone and by combined cortical and spinal lesions. They then probably represent a group of interneurons which receive convergent, monosynaptic input from both spinal and cortical sources. The removal of either source would appear to be sufficient to produce transneuronal pathology.

A group of gracilis neurons located at the most ventro-lateral portion of the cell nest zone, also demonstrated transneuronal changes following contralateral SM-1 lesions. These cells were largely unaffected by spinal lesions and their distribution was not increased by the combined lesion approach. They may represent a group of interneurons which receive monosynaptic cortical input predominantly.

The rostral zones of the DCN, which contained bilaterally symmetrical columns of pathological cells, located at the junction of the ventromedial cuneatus with the ventrolateral gracilis, following unilateral cortical lesions provide for more speculation. The location of these columns correlates well with the distribution of preterminal degeneration following destruction of the medial portion of the feline posterior sigmoid gyrus (Kusama et al., '66). Our lesions in SM-1 were mainly confined to this area. These cells were largely unaffected by spinal lesions, and their distribution was not increased by the combined lesion approach. They could then represent yet another group of interneurons which receive monosynaptic cortical input only. The fact that no additional pathology in the rostral zones was produced by combined spinal and cortical lesions leads to speculation that the synaptology within these regions may be extremely complex and perhaps other sources of afferent input exist (Cesa-Bianchi and Sotgiu, '69a).

Further investigation is, of course, needed. More cxtensive cortical lesions and/or longer degeneration intervals may produce more diffuse pathology in the regions of the DCN containing interneuronal groups. Perhaps lesions interrupting spinal, cortical and reticular formation (Cesa-Bianchi and Sotgiu, '69a) afferents to these nuclei would produce more extensive pathology. Elcctrophysiological investigation of cells located in the described areas affected by transneuronal changes following SM-1 decortications would be of obvious immediate interest. 


\begin{abstract}
Lesions were placed in the spinal cord and sensory-motor cortex of adult cats in an attempt to produce transneuronal cell degeneration in the dorsal column nuclei. Animals were sacrificed at 30,60 and 90 postoperative days. Serial sections of the cervical cord and medulla were stained with cresyl violet. Other stains utilized were periodic acid Schiff, methyl green pyronin and phosphotungstic acid-hematoxylin.

Mild cellular changes, consisting of hypochromatic staining with cresyl violet, were noted at 30 days. Both mild and severe changes (consisting of alterations in cellular shape, staining and nuclear-nucleolar size) were noted at 60 days. Mainly severe changes were observed at 90 days. Histochemical techniques revealed that severely affected cells had stainable DNA within shrunken nuclei, enlarged nucleoli and a homogeneous proteinaceous deposit within their cytoplasm and processes.

Ninety day spinal lesions involving dorsal column afferents produced dense transneuronal pathology in the caudal zone of the gracilis. The cell nest zones of the gracilis and cuneatus contained several severely affected cells within individual cell clusters. The rostral zones of both nuclei contained only scattered severely pathological cells. Ninety day unilateral cortical lesions produced dense transneuronal pathology in a limited portion of the caudal gracilis. Rostral zones of both nuclei contained bilaterally symmetrical columns of severely affected cells, located at the junction between gracilis and cuneatus, throughout the length of these zones. Results are discussed in relation to the zonal division of these nuclei and the known organization of each zone.
\end{abstract}

\title{
Literature cited
}

Anderson, P., J.C. Eccles, R. F. Schmidt and T. Yokota: Identification of relay cells and interneurons in the cuneate nucleus. J. Neurophysiol., $27: 1080-1095,1964 \mathrm{c}$.

Barron, D.H.: Structural changes in anterior horn cells following central lesions. Proc. Soc, Exp. Biol. (N.Y.), 30: 1327-1329, 1933.

Cammermeyer, J.: An evaluation of the significance of the " dark" neuron. Ergebn. Anat. Entwickl.Gesch., 36: 1-16, 1962.

Cesa-Bianchi, M. G. and M. L. Sotgiu: Control by brain stem reticular formation of sensory transmission in Burdach nucleus. Analysis of single units. Brain Res., $13: 129-139,1969$ a.

Chambers, W.W. and C.N. Liu: Cortico-spinal tract of the cat. An attempt to correlate the pattern of degeneration with deficits in reflex activity following neocortical lesions. J. Comp. Neurol., 108 : 23-56, 1957.

Chambers, W.W., C.N. Liu and G.P. McCouch: Inhibition of the dorsal column nuclei. Exp. Neurol., 7: 13-23, 1963.

Cook, W.H., J.H. Walker and M.L. Barr: A cytological study of transneuronal atrophy in the cat and rabbit. J. Comp. Neurol., 94:267-292, 1951. 
Cowan, W.M.: Anterograde and retrograde transneuronal degeneration in the central and peripheral nervous systems, pp. 217-251. In "Conzemporary Research Methods in Neuroanatomy." W. J.H. Nauta and S. O.E. Ebbesson (Eds.). SpringerVerlag, New York, Heidelberg, Berlin, 1970.

Dreschfeld, J.: The changes in the spinal cord after amputation of limbs. J. Anat. Physiol., 14: 424-431, 1879-1880.

Ferraro, A. and S.E. Barrera: Summary of clinical and anatomical findings following lesions in the dorsal column system of Macacus Rhesus monkeys. Assoc. Res. Nerv. Ment. Dis., 15: 371-395, 1935 c.

Foerster, O. and O. Gagel: Die tigrolytische reaktion der ganglienzelle. Z. Mikr.Anat. Forsch., 36: 567-575, 1934.

Gordon, G. and M.G.M. Jukes : Correlation of different excitatory and inhibitory influences on cells in the nucleus gracilis of the cat. Nature, 196:1183-1185, 1962.

Gordon, G. and M.G.M. Jukes: Descending influence on the exteroceptive organization of the cat's gracile nucleus. J. Physiol., 173: 291-319, 1964b.

Gordon, G. and R. Miller: Identification of corticofugal cells projecting to gracile and cuneate nuclei of the cat. J. Physiol., 186: 34-35, 1966.

Gordon, G. and C.H. Paine: Functional organization in nucleus gracilis of the cat. J, Physiol., 153 : 331-349, 1960.

Gordon, G. and W. A. Seed: An investigation of nucleus gracilis of cat by antidromic stimulation. J. Physiol., 155: 589-601, 1961.

Hand, P. J.: Lumbosacral dorsal root terminations in the nucleus gracilis of the cat. Some observations on terminal degeneration in other medullary sensory nuclei. J. Comp. Neurol., 126:137-156, 1966.

Karnovsky, M. J.: A formaldehyde-glutaraldehyde fixative of high osmolality for use in electron microscopy. J. Cell Biol., $27: 137 \mathrm{~A}, 1965$.

Keller, J.H. and P. J. Hand: Dorsal root projections to nucleus cuneatus of the cat. Brain Res., 20 : 1-17, 1970.

Koening, H., R. A. Groat and W.F. Windle: A physiological approach to perfusionfixation of tissue with formalin. Stain Tech., $20: 13-22,1945$.

Kupfer, C. and J.L. Downer: Ribonucleic acid content and metabolic activity of lateral geniculate nucleus in monkey following afferent denervation. J. Neurochem., $14: 257-263,1967$.

Kusama, T., K. Otani and E. Kawana: Projections of the motor, somatic sensory, auditory and visual cortices in cats, pp. 292-322. In "Progress in Brain Research," Vol. 21A. T. Tokizane and J. P. Schade (Eds.). Elsevier, Amisterdam, London, New York, 1966.

Kuypers, H.G.J.M. and J.D. Tuerk: The distribution of the cortical fibres within the nuclei cuneatus and gracilis in the cat. J. Anat., 98:143-162, 1964.

Levitt, M., M. Carreras, W.W. Chambers and C.N. Liu: Pyrämidal influences on unit activity in posterior column nuclei of cat. Physiologist, 3: 103, 1960.

Lillie, R. D.: “Histopathologic Technic and Practical Histochemistry." The Blackiston Co., New York, 1954.

Liu, C.N.: Time pattern in retrograde degenaration after trauma of central nervous system of mammals, pp. 84-93. In "Regeneration in the Central Nervous System." W.F. Windle (Ed.). Thomas, Springfield, Illinois, 1955.

Loewy, A. D.: Transneuronal changes in the gracile nucleus. J. Comp. Neurol., 147: 497-510, 1973.

Margolis, G.: Senile cerebral disease. Lab. Invest., $8:$ 335-370, 1959.

Mateer, J.E. and $\mathrm{H}$. Ha: Transneuronal degeneration in the somatic sensory relay nuclei sollowing deafferentation in the cat. Arch. Mex. de Anat., 39: 28, 1972. 
Matthews, M.R.: Further observations on transneuronal degeneration in the lateral geniculate nucleus of the macaque monkey. J. Anat. (Lond), 98: 255-263, 1964.

Matthews, M.R., W.M. Cowan and T.P.S. Powell: Transneuronal cell degeneration in the lateral geniculate nucleus of the macaque monkey. J. Anat. (Lond.), 94 : 145-169, 1960.

McComas, A. J.: Longitudinal organization of the gracile nucleus. J. Physiol., 161: 21-22, 1962.

Minkowski, M.: Über den Verlauf, die Endigung und Zentrale Repräsentation von gekreuzten und ungekreuzten Sehnervenfasern bei einigen Säugetieren und beim Menschen. Schweiz. Arch. Neurol. Psychiat., 6: 201-252; 7: 268-303, 1920.

Penman, J. and M.C. Smith: Degeneration of the primary and secondary sensory neurones after trigeminal injection. J. Neurol. Neurosurg. Psychiat., 13: 36-46, 1950.

Pinching, A.J. and T.P.S. Powell: Ultrastrnctural features of transneuronal cell degeneration in the olfactory system. J. Cell Sci., 8:253-287, 1971.

Powell, T.P.S.: Transneuronal cell degeneration in the olfactory bulb shown by the Golgi method. Nature (Lond.), 215: 425-426, 1967.

Powell, T.P.S. and S.D. Erulkar: Transneuronal cell degeneration in the auditory relay nuclei of the cat. J. Anat. (Lond.), 96: 249-268, 1962.

Reese, T.S. and M. J. Karnovsky: Fine structural localization of a blood brain barrier to exogenous peroxidase. J. Cell Biol., 34 : 207-217, 1967.

Taber, E.: The cytoarchitecture of the brain stem of the cat. I. Brain stem nuclei of cat. J. Comp. Neurol., 116: 27-69, 1961.

Terner, J.Y., J. Gurland and F. Gaer: Phosphotungstic acid-hematoxylin; spectrophotometry of the lake in solution and in stained tissue. Stain Tech., 39 : 141$153,1964$.

Terry, R. D., N.K. Gonatas and M. Weiss: Ultrastructural studies in Alzheimer's presenile dementia. Am. J. Path., 44: 269-297, 1964.

Torvik, A. : Transneuronal changes in the inferior olive and pontine nuclei in kittens. J. Neuropath. Exp. Neurol., 15: 119-145, 1956b.

Towe, A. L. and S. J. Jabbur: Cortical inhibition of. neurons in dorsal column nuclei of cat. J. Neurophysiol., $24: 488-498,1961$.

Walberg, F.: Axoaxonic contacts in the cuneate nucleus, probable basis for presynaptic depolarization. Exp. Neurol., $13: 218-231,1965$.

Walberg, F.: The fine structure of the cuneate nucleus in normal cats and following interruption of afferent fibres-an electron microscopical study with particular reference to findings made in Glees and Nauta sections. Exp. Brain. Res., 2: 107-128, 1966a.

Warrington, W. B.: On the structural alterations observed in nerve cells. J. Physiol. (Lond.), 23 : 112-129, 1898, 1899. 


\section{Explanation of Figures}

\section{Plate I}

Selected photomicrographs of cells representing each degeneration interval. All were taken from the gracilis cell nest zone following spinal lesions. Cresyl violet stain. Magnification $\times 1,000$.

$4(A, B)$ : Normal medium-sized neurons from control animal.

4 (C) : Medium-sized neuron at the 30 day interval following mid-thoracic dorsal funiculectomy and SM-1 decortication. Note pallor, loss of Nissl bodies and early vacuole formation (arrow).

4(D) : Medium-sized neuron, 30 day interval, same lesion as C. Note cytoplasmic pallor and loss of Nissl bodies.

4(E, F): Medium-sized cells, 60 day interval, mid-thoracic dosal funiculectomy. Note severe changes consisting of peripheral clustering of Nissl bodies, pale ground glass appearance of cytoplasm, nuclear shrinkage and nucleolar enlargement with diminished staining.

$4(G)$ : Medium-sized neuron, 60 day interval, same lesion as $E$ and $F$. Note marked nuclear swelling (N), nucleolar enlargement and pallor.

$4(\mathrm{H}, \mathrm{I})$ : Medium-sized neurons, 90 day interval, hemisection at C4-5. Note distinct vacuoles (arrow) in $\mathrm{H}$, and fibrillar texture of cytoplasm in $\mathrm{I}$. Both demonstrate nuclear-nucleolar changes similar to those noted at 60 days. 
Plate I

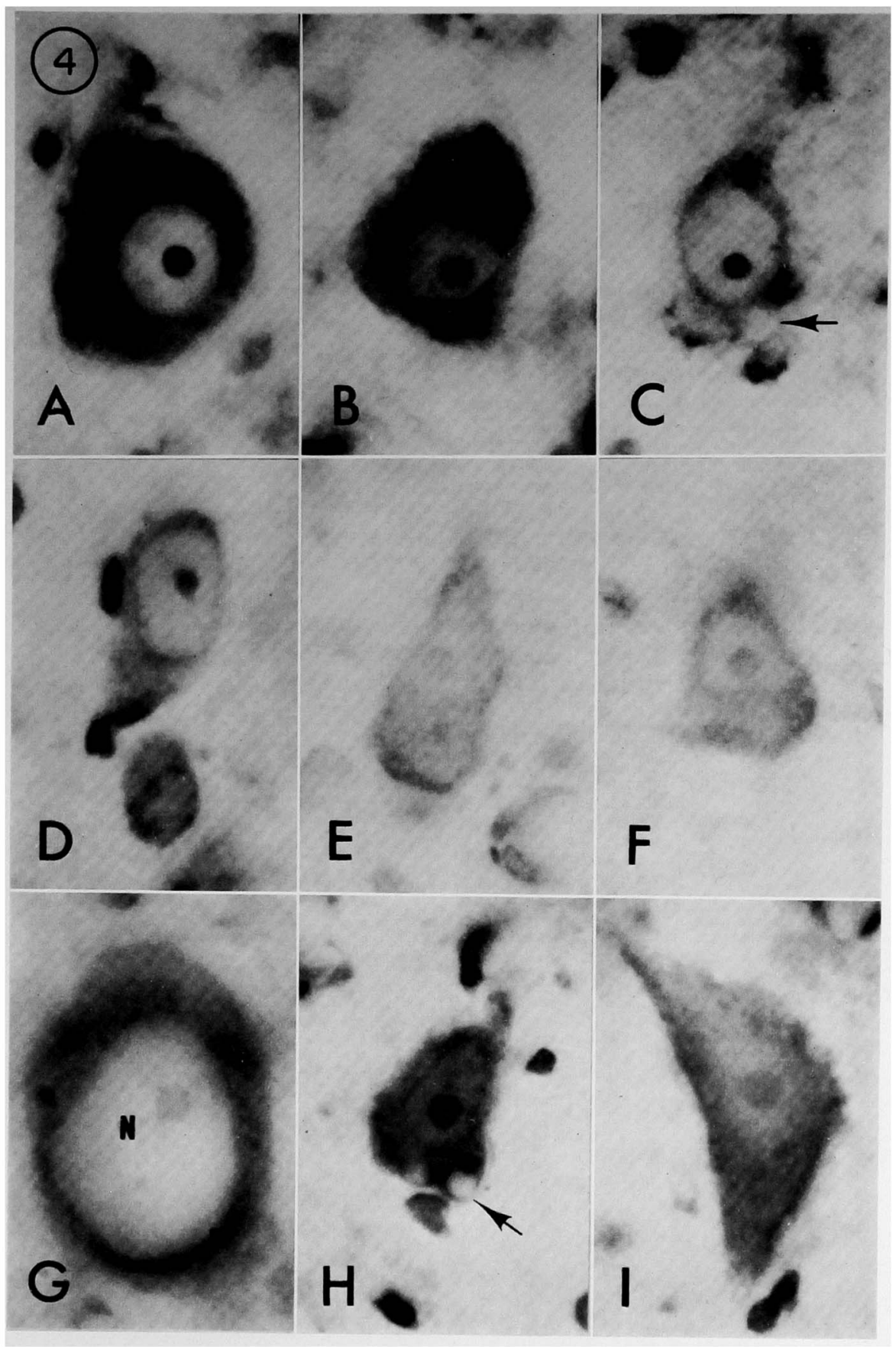




\section{Plate II}

Photomicrographs representing the appearance of severe transneuronal pathology using several histochemical techniques.

5(A): Normal large gracilis caudal zone neuron. PAS $400 x$.

$5(B)$ : Caudal zone of gracilis illustrating severely affected neurons (box) ipsilateral to a right-sided SM-1 decortication at the 90 day interval. PAS $100 \times$.

5 (C): Same cells as in B. Note dense accumulation of PAS positive material in the cytoplasm and the compressed, indistinct nucleus. PAS $400 x$.

5(D): Cuneate cell cluster at the obex level ipsilateral to hemisection at C4-5. 90 day interval. Normal cells appear much as they do with cresyl violet. Severely pathological cluster neuron (arrow) contains no distinct Nissl bodies, a homogeneous deeply stained cytoplasm with small vacuoles, a shrunken dark (blue in color) nucleus and an enlarged nucleolus. Methyl green pyronin. $400 \times$.

5 (E): Severely affected cuneate cluster cell (arrow), slightly caudal to the obex, ipsilateral to hemisection at $\mathrm{C} 4-5$. 90 day interval. Note the angular shape, the darkly stained (blue in color) cytoplasm and tortuous dendrites and the extremely dense (black in color) shruhken nucleus. PTAH $400 \times$.

$5(F)$ : Cuneate cluster cells slightly caudal to the obex ipsilateral to hemisection at $\mathrm{C} 4-5$. 90 day interval. Normal neuron (white arrow). Moderately severely affected neuron (arrow) retains normal shape but has increased cyto. plasmic and nuclear staining (red in color) and a shrunken nucleus with an enlarged black nucleolus. PTAH $400 \times$. 
Plate II

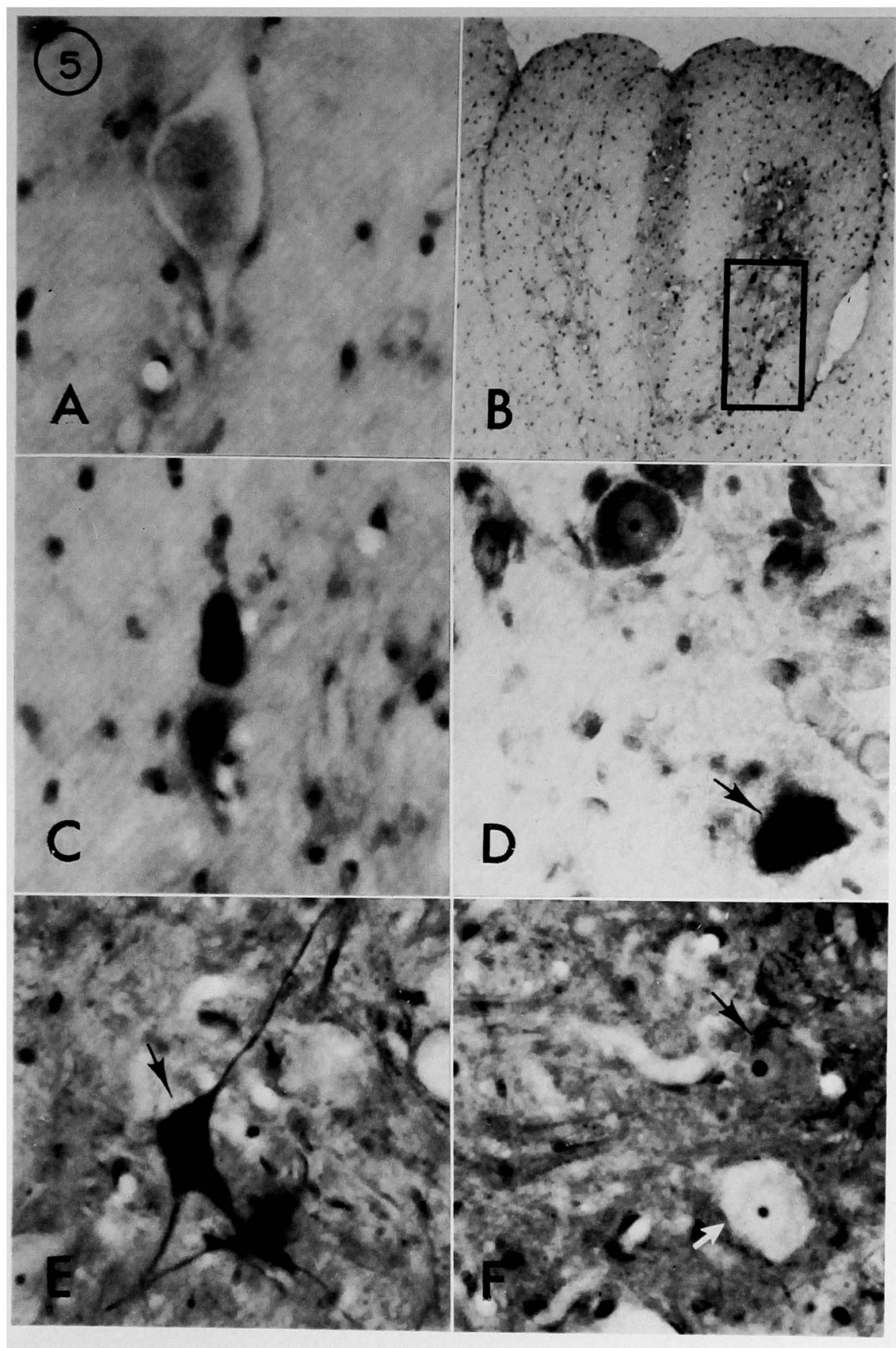




\section{Plate III}

Photomicrographs illustrating changes in the left caudal gracilis and left cell nest zone of the cuneatus following left hemisection at C4-5. 90 day interval.

6(A) : Enlargement of cells from left caudal gracilis, indicated in B. Neurons demonstrate angular shape, loss of distinct Nissl bodies and shrunken, indistinct nuclei. Cresyl violet $400 \times$.

6(B) : Note the dimished volume of the left gracilis (arrow), the marked gliosis within left nucleus and adjacent dorsal funiculus and the changes in neuronal shape and size visible at this magnification. Cresyl violet $100 \times$.

6(C) : Enlargement of normal cells from the right caudal gracilis, indicated in B. Cresyl violet $400 \times$.

$6(D, E):$ Left (D) and right (E) cuneate cell nest zones respectively. Note the marked gliosis within the left nucleus (D) especially in the dorsolateral portions and the presence of several dark, angular neurons (arrows in D) within several of the cell clusters. Cresyl violet $100 x$.

$6(F)$ : Enlargement from (D) above. Note the presence of two angular, shrunken neurons with shrunken, indistinct nuclei (arraws) within an otherwise normal appearing cell cluster. Cresyl violet $400 x$.

6(G) : Enlargement of normal cell cluster from (E) above. Cresyl violet $400 \times$. 
Plate III

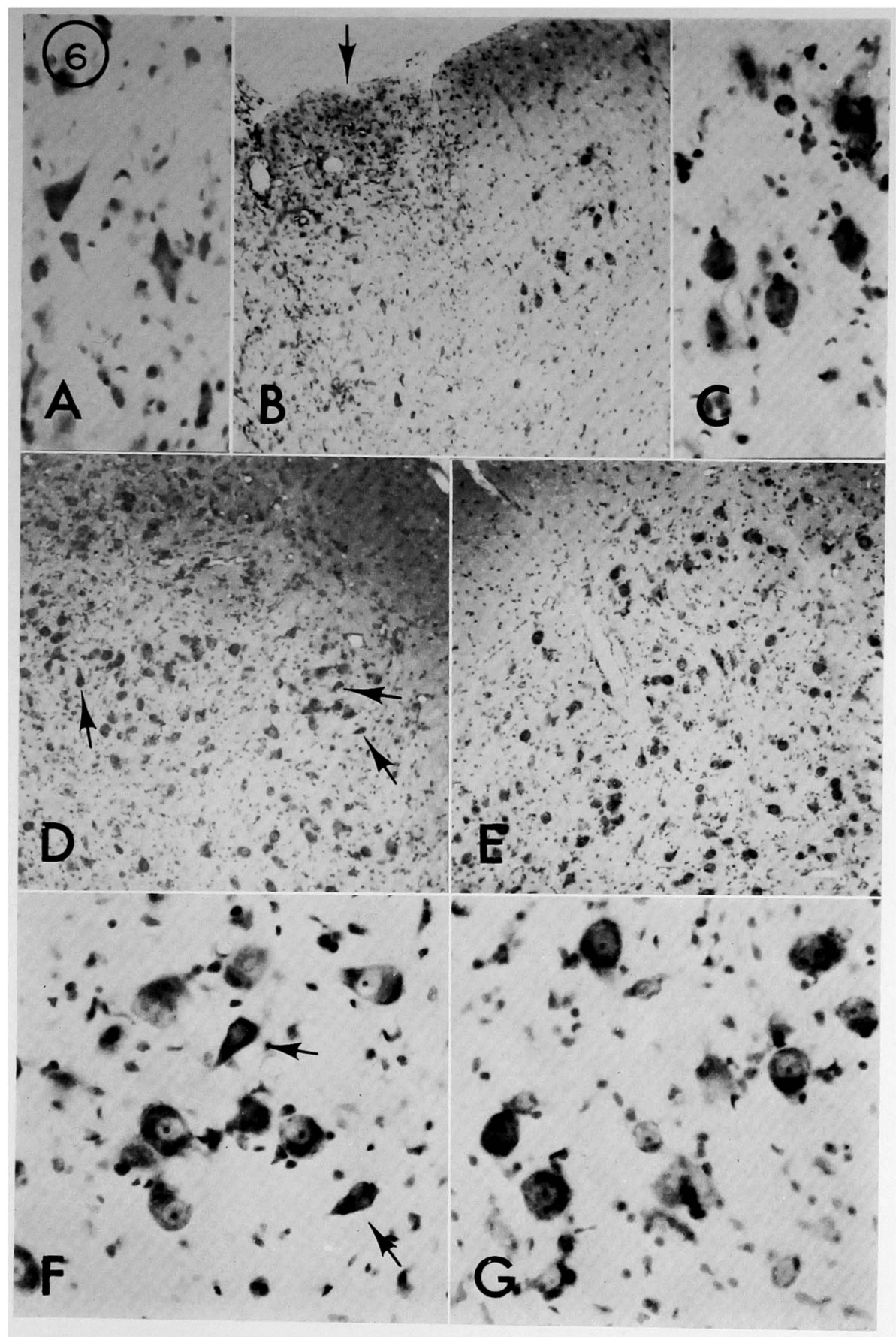




\section{Plate IV}

Photomicrographs illustrating transneuronal changes in the caudal zone of the gracilis and rostral zones of both gracilis and cuneatus following right-sided SM-1 decortication. 90 day interval.

7 (A) : Gracilis caudal zone. Note group of severely affected cells (box) in the right gracilis ipsilateral to the cortical lesion. PTAH $100 \times$.

7 (B) : Enlargement of pathological cells in (A). Normal neurons are very pale (arrow). Note both small (white arrows) and medium-sized (star) neurons demonstrating severe pathological reactions. PTAH $400 \times$.

$7(\mathrm{C}, \mathrm{D})$ : Left (C) and right (D) cuneate nuclei just caudal to the obex. Note the presence of bilaterally symmetrical groups of angular, pale staining neurons with prominent processes (arrows) in the ventromedial portions of both cuneati. Cresyl violet $100 \times$.

$7(\mathrm{E}, \mathrm{F})$ : Enlargement of pathological cells from (C) and (D) above respectively. Note the nuclear shrinkage and the enlarged, pale nucleolus in the cell in (F) (arrow), the prominence of dendritic staining and the lack of a distinct nucleus in the cell in (E) (arrow) and the loss of distinct Nissl bodies with resultant pallor of both cells when compared to normal neurons. Cresyl violet $1,000 \times$. 
Plate IV

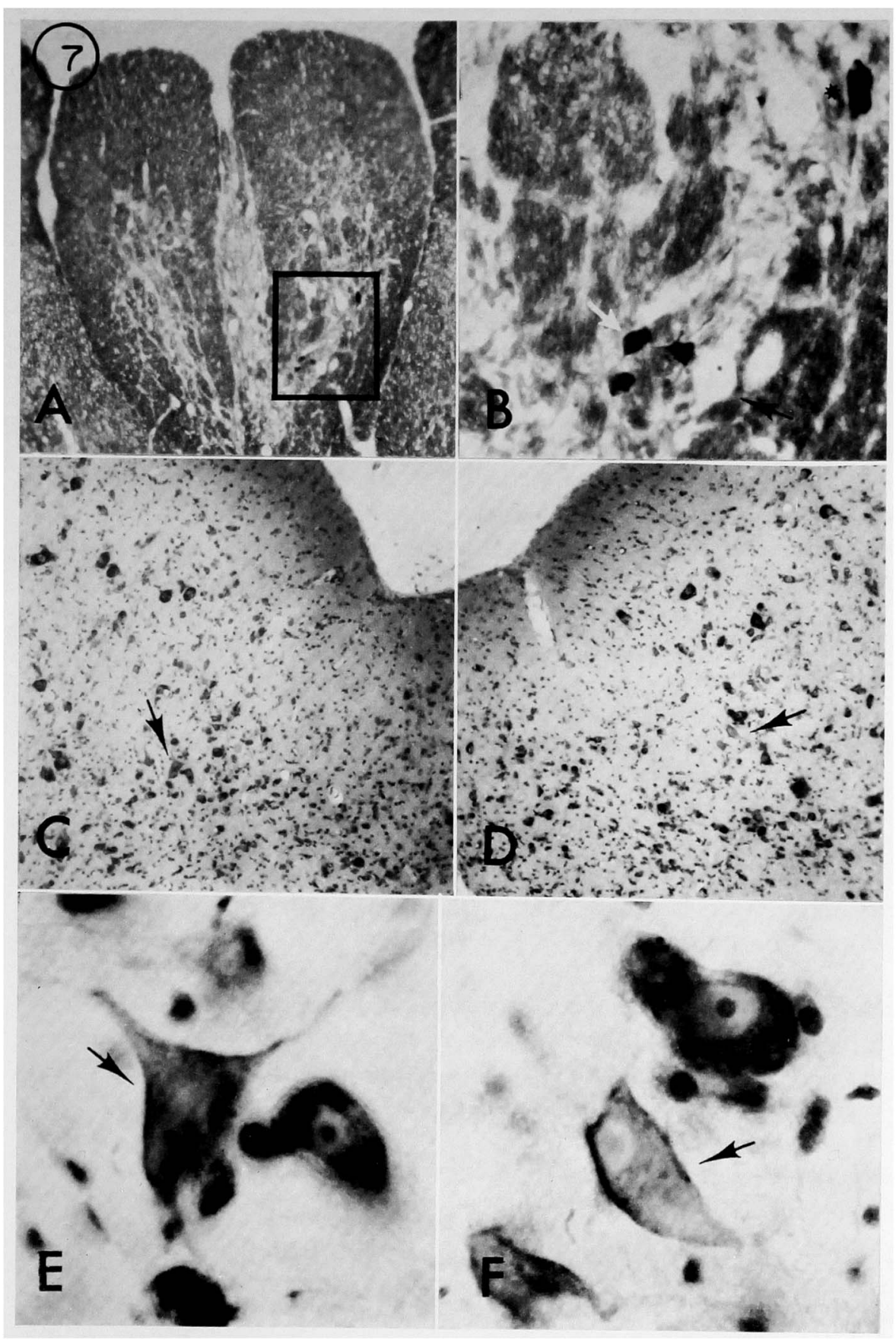

